\title{
Research on the Development Strategies of Open Universities under the Environment of Jiangyin County
}

\author{
Wei Cao \\ Jiangyin Polytechnic College \\ Jiangyin, Jiangsu, 214405
}

\begin{abstract}
On the basis of making clear the positioning, function and system of open universities under the county economy and industrial environment of Jiangyin county, this article uses SWOT model to analyze the external opportunities and threats faced by Jiangyin Open University, the internal strengths and weaknesses, and puts forward the development strategies for Jiangyin Open University; it is requested to raise awareness of openness, update education concept, and accelerate the top-level design; emphasize discipline construction, improve scientific research atmosphere, and promote informatization construction; optimize professional layout, highlight demand orientation, and create characteristic learning center; and gather qualified resources, standardize service process and unify teaching quality.
\end{abstract}

Keywords-Jiangyin Open University; SWOT analysis; Development strategies

\section{OVERVIEW TO JIANGYIN OPEN UNIVERSITY}

In December 2014, Jiangyin Municipal People's Government issued a document about renaming Wuxi Radio and Television University Jiangyin Branch School as Jiangyin Open University, and made clear that Jiangyin Open University is a new comprehensive university led by Jiangyin Municipal Government, and Municipal Education Bureau, with independent school-running right, and as per the "college+ platform+ center" positioning structure, it accepts the teaching and management of Jiangsu Open University, takes network technology and informatization platform as the means, play the system construction strengths of all streets (towns) in Jiangyin City, carries out modernized remote open education, and it is the important component for higher education in Jiangyin, and is also the public welfare education service institution; Jiangyin Open University system keeps a foothold on Jiangyin, serves Jiangyin and fully utilizes the brand new education mode and education strengths of open universities, builds and integrates the mechanism platform of various education resources, fully utilizes the rich education resources of open universities, establishes the biggest higher education base for in-service personnel, the biggest remote further education base, and finally establishes the biggest social learning service platform in Jiangyin, and the main function thereof is to continuously and stably develop adult higher education, actively develops non-academic education and establishes lifelong learning "flyover".

In September, 2015, the construction scheme of Jiangyin Open University stipulated that Jiangyin Open University must conduct well the comprehensive transformation of schoolrunning mode and connotation construction of open universities; meanwhile, it has also revised and perfected the Learning Center Construction and Management Regulations (Discussion Draft) of Jiangyin Open University on the basis of the brand new exploration and research considering five aspects, including the construction of supporting system, the construction of school-running organization system, the construction of teaching informatization, the teaching mode reform, and the construction of "credit bank", and has also made clear that the street (town) learning center of Jiangyin Open University is the primary-level organization set at all streets (towns) of Jiangyin City for teaching and management service, and is also the place to provide guidance and service for vast learners within the jurisdiction, and the learning center is built on the basis of the adult teaching center school or community education center of all streets (towns) in Jiangyin City, and can provide recruitment consultation, training service, management linkage and other relevant basis guarantees for Jiangyin Open University to carry out the promotion of academic education and the tainting of nonacademic education, and the learning center is affiliated to the street (town) where it locates in administration, and in business, it shall accept the guidance and management of Jiangyin Open University, so this has formed the " $1+17$ " secondary system structure management mode for the learning center with 17 street (town) adult education center schools or community education centers through taking the informatization platform of Jiangyin Open University as the subject. 
kinds of learners as the service objects, and the credit management as the service contents, and is aimed to promote the intercommunication of all kinds of higher academic education, and the linkage of academic education and nonacademic education as well as the pre-service education and post-service education, and it has provided a personalized lifelong learning service credit management service for learners.

During the "13th Five Year Plan" period, in order to deeply implement the "simplifying administrative procedures, delegating powers to lower levels, delegating power and strengthening regulation, and optimizing the service" reform deployment requirements of the State Council, Jiangyin Municipal Government and all levels of town governments have successively established the government affair service center, and further reinforced the standardization and unification of personnel in municipal, town and village-level management functional department as well as management and technical personnel in enterprises above designated size in the entire city, the highly educated and highly skilled talents and talent reservation and other management requirements

\section{B. External threats $(T)$}

There are still many disputes in all sectors of society over whether the Open University of China and Jiangsu Open University are the simple reproduction, transformation or listing of the former China Central Radio \& TV University and Jiangsu Radio \& TV University

The homogeneous competition among the teaching points of institutions of higher learning that set higher education further education in Jiangsu Province and are regularly filled inside and outside the province is intense, and disordered competition among unfilled and private teaching points is also highlighted, and the school-running has no rules to follow, which has brought many troubles to the school-running expectation and development reform of open universities.

The impact, reconstitution, treats, etc. of thinking mode, teaching mode and the new changes and new trends brought by the University of Phoenix, British Open University, French Remote Education Center and other international remote education development have directly influenced the doubts about the school-running quality of open universities or it is held to be the awkwardness of repeated construction and other issues [1]

Along with the enrollment expansion of regular higher education, the popularization of higher education popularization, the constant decrease of student sources taking college entrance examinations in Jiangsu Province as well as the obvious confusion and replacement function of national adult college entrance examination, self-taught examination, college network education and other traditional and modernized adult higher education modes for the emergent novelty of open universities, open universities are now in an awkward situation of surviving in cracks.

Along with the state energetically developing the central and western regions, the income difference for industrial workers in the eastern coastal region and the central and western regions has been further shrunk, and the awareness for

Information Platform was officially operated online in 2016 and it takes the lifelong education concept as the guidance, all 
protecting the stay-at-home children and empty-nest elderly, etc. has been further reinforced, and this will directly cause the decrease in the quantity of external population, and form certain decrease in the quantity of potential student sources in regional open universities.

\section{Internal strength $(S)$}

Jiangyin Open University is a new institution of higher learning sponsored by the Municipal Government, managed by the Municipal Education Bureau, accepts the business guidance of Jiangsu Open University, takes the modernized information technology as the support, and carries out remote open education for all people; it mainly undertakes the academic education and non-academic further education task oriented to junior college and undergraduate education.

Jiangyin Municipal People's Government establishes Jiangyin Open University on the basis of Jiangyin Polytechnic College, which is the only higher vocational college in the entire city, and it emphasizes on the local industrial structure, and has opened above 40 specialties, and can basically cover all industries and industrial development transformation and other requirements in Jiangyin City, and can directly serve the local economic transformation and social development.

Jiangyin Open University puts forward " $1+17$ " secondary system structure management mode through relying on various town and street community education centers in the entire city, and has basically formed the secondary school-running mode with sound infrastructure construction, sound personnel configuration, standardized system construction, and it can support thoughtful service, with clear division of labor at post.

Jiangyin lifelong learning website is sponsored by Jiangyin Municipal People's Government, and then under the lead of the Municipal Education Bureau and by virtue of the resources and technical strengths accumulated by Jiangyin Polytechnic College in combination with the experience and achievements of all town and street community education centers in the entire city, it is a lifelong learning platform oriented to all citizens in Jiangyin, and can further promote the development of Jiangyin Open University in scope and depth.

Jiangyin Open University has promoted the comprehensive transformation of adult higher education school-running mode and connotation construction in the entire city, promoted the lifelong learning of all citizens, promoted education fairness and the improvement of education quality, and has formed the benchmark and flag of regional adult higher education.

\section{Internal weakness (W)}

Although the " $1+17 "$ secondary system structure management mode of Jiangyin Open University has implemented hardware construction as per the Learning Center Construction and Management Regulations of Jiangyin Open University (Discussion Draft), the software construction still needs to be reinforced and perfected, and the management personnel and mode cannot adapt to the school-running mode of Jiangsu Open University yet.

Along with the education informatization process being constantly promoted, MOOCs, flipped classroom and other teaching mode have promoted the constant reform of the modernized remote education teaching mode, and driven the " $1+17$ " secondary system management personnel of Jiangyin Open University to march forward, and it is requested to constantly improve the post competency and responsibility consciousness of the teaching and management personnel, and conduct well the change of roles.

Since Jiangyin Open University is constructed on the basis of the full-time state-run vocational colleges of Jiangyin Polytechnic College, it is restricted by the public institution system and mechanism, and as for the regional recruitment, teaching, practice and other achievement award and punishment mechanism, it is requested to strictly execute the public institution management regulations, and cannot fully break through the system, mechanism and other restriction bottlenecks.

Due to the unbalanced and unsound development of various regions, this has caused the decrease in the conformity of teaching quality and talent cultivation in Jiangyin Open University, and since the student management and teaching quality are uneven, and the scientific research, discipline and professional level are relatively weak, it cannot fully adapt to the teaching management requirements of Jiangsu Open University and Jiangyin Open University.

\section{DEVELOPMENT STRATEGIES OF JIANGYIN OPEN UNIVERSITY}

\section{A. Improve open awareness, update education concept, and accelerate top-level design}

The Reports of the 19th National Congress of the Communist Party of China put forward the new requirements of "conducting well the further education, accelerating the construction of learning-type society, and energetically improving the quality of the nation", and in order to conduct well the further education, it cannot be separated from lifelong education and the universal education, and it is requested to build the learning-type society that can realize "all people learning everywhere and anytime", and meet the diversified lifelong learning demand of the people. Open universities have three functions, including talent cultivation, scientific research and social service, and high-quality undergraduate education is the footstone for establishing open universities, and the nonacademic education under lifelong education system is the main market for the sustainable development of open universities, and the valid approach for the construction of open universities is to adopt several measures to carry out academic education and non-academic training.

At the beginning for the establishment of Jiangyin Open University, it has made clear the school-running tenet for keeping a foothold on Jiangyin, constructing Jiangyin and serving Jiangyin, and then fully utilized the advanced education concept of open universities, the scientific education method and rich education resources, and closely contacted with Jiangyin Municipal Education Bureau and Human Resources and Social Security Administration, updated concept and ideas, established a benchmark and model, played a leading and demonstration role, separately promoted the organic integration 
of adult higher education resources in Jiangyin City, established the further education base for in-service staff in Jiangyin City, and promoted the construction of social learning service platform of Jiangyin Open University.

\section{B. Emphasize discipline construction, improve scientific research atmosphere, and promote informatization construction}

The discipline construction is the basis for the talent cultivation of open universities, and open universities have multiple properties and diversified characteristics of regular higher education and professional education, further adult further education and non-academic education, etc., and the education object also has characteristics such as big regional difference, big individual difference, and diversified requirements, and this has decided that various discipline constructions of open universities must be wide, and the course system shall flexibly expand disciple direction, and the discipline system shall be organically penetrated and mutually integrated, and the discipline structure shall be validly adjusted and adapt to changes[2].

By virtue of Jiangyin Polytechnic College, Jiangyin Open University combines the guidance opinions about the discipline construction of Jiangyin Open University, and then in the discipline construction concept, it continuously imports the active meanings and conversion function of economic construction development and industrial structure transformation under the county environment of Jiangyin into the discipline construction development of open universities, and highlights the equal development and dual-wheel driving of main discipline and characteristic discipline in open universities, fully utilizes information technology, builds and constructs network learning and academic research atmosphere, and then through validly transplanting the scientific research management system and motivation evaluation mechanism of Jiangyin Polytechnic College, to improve the reflection and enthusiasm of Jiangyin Open University about the discipline construction; carries out course teacher informatization teaching competition, micro-course fabrication training and other valid approaches, to further promote the informatization construction of Jiangyin Open University, promote the integrated development of information technology and open education, so as to improve the teacher team and discipline construction capacity of Jiangyin Open University as a whole.

\section{Optimize professional layout, highlight demand orientation, and create characteristic learning center}

Jiangyin Open University adheres to the school-running concept of "the dual cultivation of virtues and academic study, and the equal emphasis on quality and credibility" in " $1+17$ " secondary system structure management mode, and then specific to different county industrial patterns of Jiangyin, as per the demand analysis of different regional characteristics, different industrial structure, and different development layers in all streets (towns) of Jiangyin City, Jiangyin Open University and " $1+17$ " secondary management learning center have carried out open questionnaire investigation, made sure that the school-running direction and industrial development of all street (town) learning centers of Jiangyin Open University can be anastomotic, the discipline construction and industrial prospect can be matched, the professional construction and enterprise development can be consistent, and the course system and product $R \& D$ can be integrated, and then it has further made clear that Jiangyin Open University shall highlight the optimized layout of regional characteristic learning center on the basis of system school-running.

In the collaborated school-running process, Jiangyin Open University has highlighted the characteristic construction of various street (town) learning centers, and each learning center can actively adjust the cultivation direction and training objective as per the regional industrial characteristics, highlight the discipline construction, focus on industrial development objective, and the training course system is set as per the enterprise products and $\mathrm{R} \& \mathrm{D}$ requirements, and it adopts "education background+ skills" combined training mode, focuses on improving the professional quality and professional skills of the in-service personnel, creates the regional learningtype enterprises of the learning center, and further improves the industrial core competitiveness of the regional industry.

\section{Gather qualified resources, standardize service procedures, and unify teaching quality}

Jiangyin Open University has actively undertaken the task for constructing the lifelong learning public service platform for citizens in Jiangyin, and it has opened "Jiangyin Lifelong Learning Website" for above 2.2 million registered citizens in Jiangyin, with strong online popularity, practicability and enjoyment, and there have been above ten thousand qualified video resources and school-based self-built resources with the regional cultural characteristics of Jiangyin, and they are all opened to the learners free of charge.

Specific to the " $1+17$ " secondary system framework management mode of Jiangyin Open University, it has carried out the standardization of service procedure normalization and teaching quality unification, studied and released the Dynamic Tracking Management Methods of Service Quality in Jiangyin Open University and the Management Performance Evaluation Management Methods of Jiangyin Open University, and made clear the normalization and standardization of various business procedures within the system of Jiangyin Open University.

\section{CONCLUSION}

On the basis of studying the school-running orientation, function and management system of open universities under the county economy and industry environment of Jiangyin, this article uses SWOT model to analyze the opportunities and threats faced by Jiangyin Open University, the existing strengths and weaknesses, and then specific to the " $1+17$ " secondary system structure management mode of Jiangyin Open University, it puts forward targeted development strategies. The research results have indicated that Jiangyin Open University has actively planted the county economy and industry structure of Jiangyin into the discipline construction of open universities under the precondition of making clear the advanced concept and scientific method of open universities, and then further highlights the characteristic construction of all street (town) learning centers, and then through normalizing 
and unifying all business procedures and quality standards within the system of Jiangyin Open University, it is aimed to promote the learning-type enterprise construction and learningtype social construction, and finally put forward constructive opinions and suggestions for open universities under county environment, and provide referential mode for the construction of lifelong education system.

\section{ACKNOWLEDGMENT}

Fund Project: One of the research achievements for the Scientific Research Topic of Jiangyin Polytechnic College in 2017 Research about the Development Strategies of Street (Town) Learning Centers in Jiangyin Open University (No.: 17S-XZ-03).

About the Author: Wei Cao, male, associate researcher, and the main research direction is education management and remote education.

\section{REFERENCES}

[1] Xin Ding. New Technology, New Environment, New Challenge and New Opportunity_Environment, Bottleneck and Strategy Suggestions about the development of the Open University [J]. Journal of the Open University of Guangdong, 2017, 26 (01): 20-30.

[2] Wenjing $\mathrm{Xu}$ and Liu Zituan. Initial Discussion about the Discipline Construction of the Open University [J]. Lifelong Education Research, 2017, 28(02): 23-28+54. 